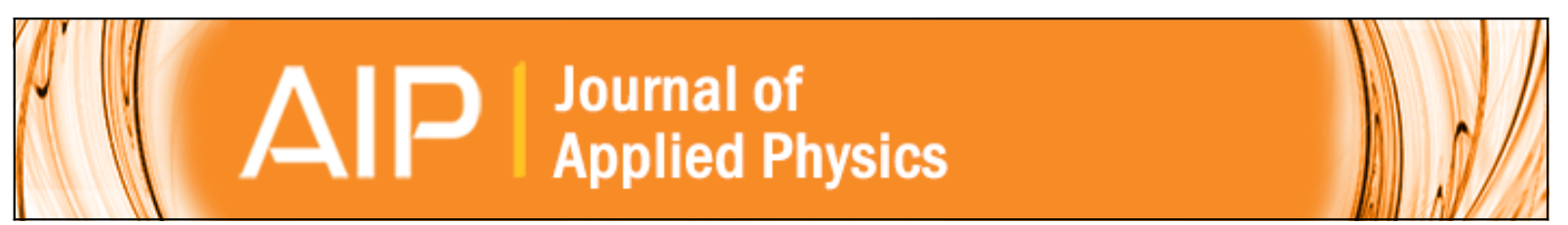

Selective formation of large-grained, (100)- or (111)-oriented Si on glass by Al-induced layer exchange

K. Toko, R. Numata, N. Saitoh, N. Yoshizawa, N. Usami, and T. Suemasu

Citation: Journal of Applied Physics 115, 094301 (2014); doi: 10.1063/1.4867218

View online: http://dx.doi.org/10.1063/1.4867218

View Table of Contents: http://scitation.aip.org/content/aip/journal/jap/115/9?ver=pdfcov

Published by the AIP Publishing

AlP Re-register for Table of Content Alerts 


\title{
Selective formation of large-grained, (100)- or (111)-oriented Si on glass by Al-induced layer exchange
}

\author{
K. Toko, ${ }^{1, a)}$ R. Numata, ${ }^{1}$ N. Saitoh, ${ }^{2}$ N. Yoshizawa,${ }^{2}$ N. Usami, ${ }^{3}$ and T. Suemasu ${ }^{1}$ \\ ${ }^{1}$ Institute of Applied Physics, University of Tsukuba, 1-1-1 Tennodai, Tsukuba, Ibaraki 305-8573, Japan \\ ${ }^{2}$ Electron Microscope Facility, TIA, AIST, 16-1 Onogawa, Tsukuba 305-8569, Japan \\ ${ }^{3}$ Materials, Physics and Energy Engineering, Nagoya University, Aichi 464-8603, Japan
}

(Received 19 January 2014; accepted 18 February 2014; published online 3 March 2014)

\begin{abstract}
By controlling the Si thickness and the annealing temperature used for Al-induced crystallization, we controlled the fraction of (100) and (111) orientations of polycrystalline Si (poly-Si) grains grown on glass. Changing the proportions of crystal orientation strongly influenced the average grain size of the poly-Si layer. By growing a 99\% (111)-oriented poly-Si layer, formed with a 50-nm-thick Si layer at $375^{\circ} \mathrm{C}$, we produced a Si layer with grains nearly $40 \mu \mathrm{m}$ in size. We discuss the growth mechanism from the perspective of competition between (100)- and (111)-oriented nuclei. This achievement holds promise for fabricating high-efficiency thin-film solar cells on inexpensive glass substrates. (C) 2014 AIP Publishing LLC. [http://dx.doi.org/10.1063/1.4867218]
\end{abstract}

\section{INTRODUCTION}

Forming large-grained polycrystalline $\mathrm{Si}$ (poly-Si) on glass at low temperatures has been widely studied for fabricating inexpensive thin-film solar cells with high-conversion efficiencies, because poly-Si cells with sufficiently large grains $(>10 \mu \mathrm{m})$ can exhibit efficiencies nearly that of cells made from single-crystalline $\mathrm{Si}^{1-3}$ Besides, orientationcontrolled poly-Si layers are essential for fabricating antireflective structures, controlled nanostructures, and tandem structures with advanced materials. ${ }^{4-6}$

Al-induced crystallization (AIC) has gained much attention as a way to form poly-Si on glass below the softening temperature of glass $\left(\sim 550^{\circ} \mathrm{C}\right)$. In this technique, an amorphous $\mathrm{Si}(\mathrm{a}-\mathrm{Si})$ layer on $\mathrm{Al}$ is crystallized by exchanges between the $\mathrm{Al}$ and $\mathrm{Si}$ layers during annealing $\left(425-500{ }^{\circ} \mathrm{C}\right) .^{7-13} \mathrm{AIC}$ allows for orientation control in large-grained poly-Si layers. ${ }^{14-17}$ Because the AIC-Si layer is doped p-type from residual $\mathrm{Al}$ atoms in the $\mathrm{Si}$ layer, researchers expect it to be useful as a seed layer for growth of a Si light-absorption layer by epitaxial thickening techniques. ${ }^{2,18-20}$

Fabricating the solar cell and characterizing its electrical properties both require a conducting layer under the poly-Si layer. To accomplish this, some researchers have investigated AIC of a-Si on conducting layers, ${ }^{21}$ while others have investigated inverted AIC. ${ }^{7,22-24}$ Inverted AIC begins with an $\mathrm{Al} / \mathrm{a}-\mathrm{Si} /$ substrate structure, contrasting the a$\mathrm{Si} / \mathrm{Al} /$ substrate structure used in normal AIC. During annealing, an $\mathrm{Al}$ conducting layer forms under the poly-Si layer via self-organizing layer exchange. In an earlier report, we found that the crystal orientation of the poly-Si layer strongly depended on the thicknesses of the original $\mathrm{Si}$ and $\mathrm{Al}$ layers. ${ }^{25}$ However, it remains uncertain what parameters influence the grain size of the poly-Si layer, one of the most important factors for thin-film solar cells. In this paper, we performed inverted AIC of a-Si and studied the correlation

${ }^{\text {a)} E-m a i l ~ a d d r e s s: ~ t o k o @ b k . t s u k u b a . a c . j p ~}$ between the crystal orientation and the grain size; from these results, we discuss a way to enlarge the grain size in the poly-Si layer, promising for designing high-efficiency polySi thin-film solar cells.

\section{EXPERIMENT}

Amorphous Si layers [thickness $\left(t_{\mathrm{Si}}\right): 50-400 \mathrm{~nm}$ ] were prepared on $\mathrm{SiO}_{2}$ glass substrates. $\mathrm{SiO}_{2}$ membranes were prepared on the a-Si layers by sequentially dipping the samples in ammonium hydrogen-peroxide mixture solution $\left(\mathrm{NH}_{4} \mathrm{OH}: \mathrm{H}_{2} \mathrm{O}_{2}: \mathrm{H}_{2} \mathrm{O}=1: 1: 10\right)$ for $30 \mathrm{~min}$ at $80^{\circ} \mathrm{C}$. Al layers with the same thickness as the a-Si layers were then prepared on the $\mathrm{SiO}_{2}$ membranes. $\mathrm{Si}$ and $\mathrm{Al}$ were deposited at room temperature by using RF magnetron sputtering with $\mathrm{Ar}$ plasma. The samples were then annealed at temperatures $\left(T_{\mathrm{a}}\right)$ of $325-450^{\circ} \mathrm{C}$ in $\mathrm{N}_{2}$ ambient for $1-100 \mathrm{~h}$. Figure 1(a) shows a schematic of the sample structure. During annealing, the surface morphology of each sample was observed by using Nomarski optical microscopy. The crystal orientations and the grain sizes of the resulting poly-Si layers were characterized by electron backscatter diffraction (EBSD) analysis. Prior to the EBSD measurements, the surface of the poly-Si layer was cleaned using a diluted HF solution $(1.5 \% \mathrm{HF})$ for $1 \mathrm{~min}$. The detailed crystal structure was observed using a FEI Tecnai Osiris transmission electron microscope (TEM), operated at $200 \mathrm{kV}$, and a TOPCON EM-002B $\mathrm{TEM}$, operated at $120 \mathrm{kV}$. Elemental composition profiles were measured with a high-angle annular dark-field (HAADF) scanning transmission electron microscope (STEM) with a probe diameter of $\sim 1 \mathrm{~nm}$, as well as with an energy-dispersive $\mathrm{x}$-ray spectrometer (EDX). Cross-sectional TEM samples were prepared by milling with a focused ion beam.

\section{RESULTS AND DISCUSSIONS}

Figures 1(b)-1(d) show Nomarski optical micrographs of the sample with $t_{\mathrm{Si}}=50 \mathrm{~nm}, T_{\mathrm{a}}=325^{\circ} \mathrm{C}$, revealing how its morphology changed over time. During annealing, the $\mathrm{Si}$ 
(a)
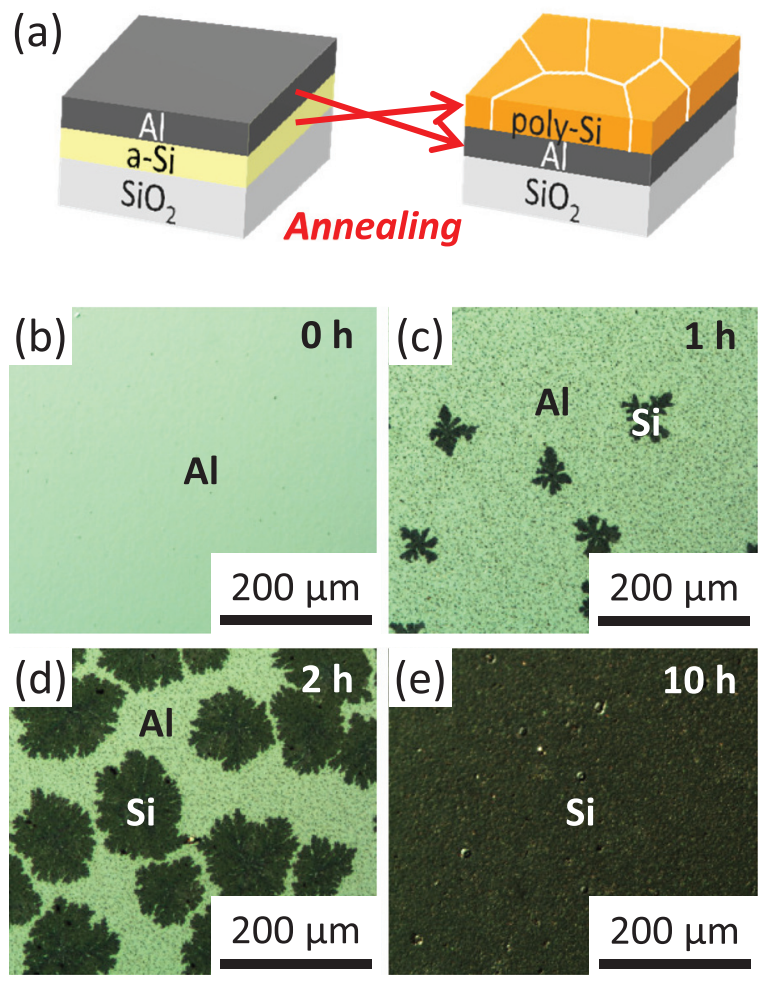

FIG. 1. (a) Schematic of layer exchange during inverted AIC of a-Si. (b)-(e) Nomarski optical micrographs of the 100-nm-thick sample, annealed at $425^{\circ} \mathrm{C}$ for (b) $0 \mathrm{~h},(\mathrm{c}) 1 \mathrm{~h}$, (d) $2 \mathrm{~h}$, and (e) $10 \mathrm{~h}$; the dark area corresponds to $\mathrm{Si}$, while the bright area corresponds to $\mathrm{Al}$.

atoms diffused to the $\mathrm{Al}$ layer, grew laterally, and then covered the entire surface of the sample. This surface morphology is almost identical to the morphology of the back surface in AIC samples, observed through transparent $\mathrm{SiO}_{2}$ substrates. ${ }^{14-17}$

Figure 2 shows crystal-orientation maps of the poly-Si layers in a matrix of $T_{\mathrm{a}}$ and $t_{\mathrm{Si}}$. For the sample with $t_{\mathrm{Si}}=50 \mathrm{~nm}, T_{\mathrm{a}}=325^{\circ} \mathrm{C}$, layer exchange did not finish within $100 \mathrm{~h}$. We attribute this low growth rate to the difficulty of layer exchange, as described in our previous study on AIC-Ge. ${ }^{26}$ The crystal orientation clearly depended on $t_{\mathrm{Si}}$ : (111) was dominant for small $t_{\mathrm{Si}}$ [Figs. 2(a) and 2(b)], while (100) was dominant for large $t_{\mathrm{Si}}$ [Figs. 2(f)-2(h)]. Note that, in the $100-n m-t h i c k$ sample, the crystal orientation clearly depended on $T_{\mathrm{a}}$ : (111) was dominant for small $T_{\mathrm{a}}$ [Fig. 2(c)], while (100) was dominant for large $T_{\mathrm{a}}$ [Fig. 2(e)] .

Using EBSD analysis, we calculated the fractions of crystal orientations in the poly-Si layers as a function of $T_{\mathrm{a}}$, summarized in Figs. 3(a) and 3(b). By definition, the (100) and (111) fractions contain planes with tilts up to $15^{\circ}$ from the exact (100) and (111) planes, respectively. For all samples $\left(t_{\mathrm{Si}}: 50,100,200,300\right.$, and $\left.400 \mathrm{~nm}\right)$, the (100) fraction increased with increasing $T_{\mathrm{a}}$, while the (111) fraction increased with decreasing $T_{\mathrm{a}}$. The greatest orientation fractions were $88 \%$ (100) for the sample with $t_{\mathrm{Si}}=200 \mathrm{~nm}$, $T_{\mathrm{a}}=425^{\circ} \mathrm{C}$ and $99 \%$ (111) for the sample with $t_{\mathrm{Si}}=50 \mathrm{~nm}$, $T_{\mathrm{a}}=375^{\circ} \mathrm{C}$. Thus, using different $t_{\mathrm{Si}}$ and $T_{\mathrm{a}}$ in inverted AIC controls the crystal orientation of the poly-Si layer, between the (100) and (111) planes. Changing $T_{\mathrm{a}}$ most strongly affected crystal orientation in the sample with $t_{\mathrm{Si}}=100 \mathrm{~nm}$, which has lower orientation compared to the other samples.

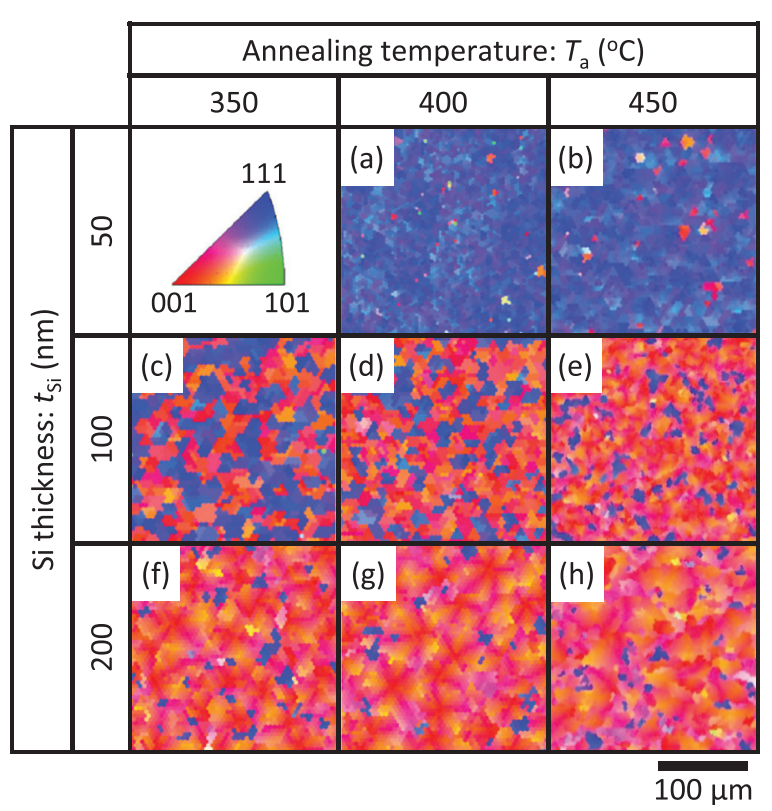

FIG. 2. (a)-(h) EBSD images of inverted-AIC-Si layers, summarized as a matrix of $T_{\mathrm{a}}\left(350,400\right.$, and $\left.450^{\circ} \mathrm{C}\right)$ and $t_{\mathrm{Si}}(50,100$, and $200 \mathrm{~nm})$. Coloration indicates crystal orientation, according to the legend.

We used EBSD analysis to determine the average grain size of the poly-Si layers, summarized in Fig. 3(c) as a function of $T_{\mathrm{a}}$. The grain size decreased with increasing $T_{\mathrm{a}}$ for the sample with $t_{\mathrm{Si}}=50 \mathrm{~nm}$, while the samples with $t_{\mathrm{Si}}=200-400 \mathrm{~nm}$ exhibited the opposite behavior. In contrast, the grain size of the sample with $t_{\mathrm{Si}}=100 \mathrm{~nm}$ did not depend on $T_{\mathrm{a}}$. Thus, how grain size depended on $T_{\mathrm{a}}$ differed

$\Delta: 50 \mathrm{~nm}$ ๑: $100 \mathrm{~nm}$ 口: $200 \mathrm{~nm} \triangleright: 300 \mathrm{~nm}$ 口: $400 \mathrm{~nm}$
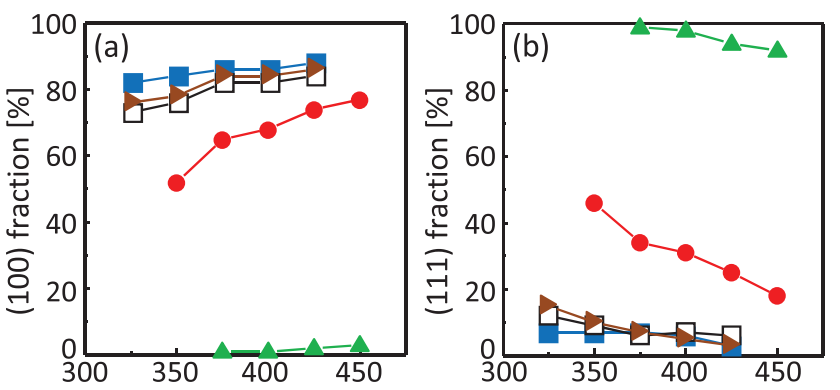

Annealing temperature: $T_{\mathrm{a}}\left[{ }^{\circ} \mathrm{C}\right]$

Annealing temperature : $T_{\mathrm{a}}\left[{ }^{\circ} \mathrm{C}\right]$
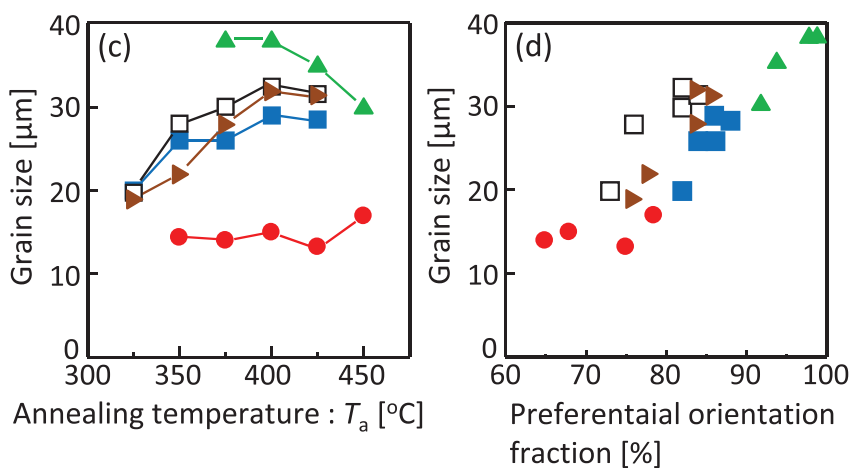

FIG. 3. EBSD characterization of the inverted-AIC-Si layers with $t_{\mathrm{Si}}=50$, $100,200,300$, and $400 \mathrm{~nm}$, showing how various properties depended on annealing temperature: (a) fraction of (100) orientation, (b) fraction of (111) orientation, and (c) average grain size. (d) Average grain size as a function of the fraction of preferential orientation [i.e., (100) or (111)]. 

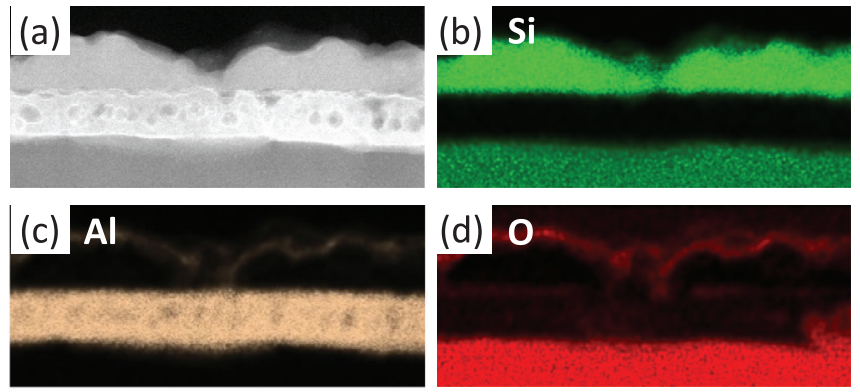

(e)

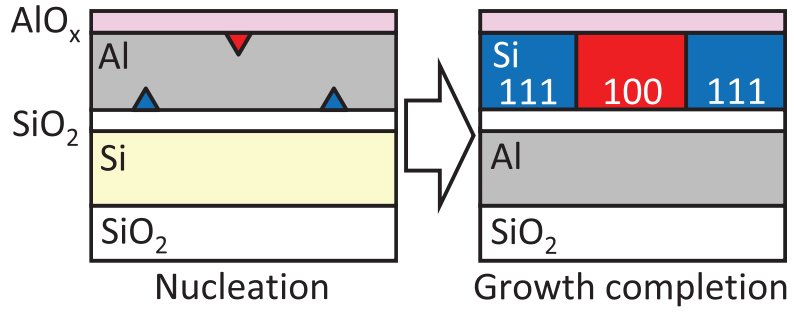

FIG. 4. Cross-sectional TEM micrographs and analysis of the sample with $t_{\mathrm{Si}}=50 \mathrm{~nm}, T_{\mathrm{a}}=375^{\circ} \mathrm{C}$. (a) STEM-HAADF micrograph. (b)-(d) EDX elemental maps of (b) $\mathrm{Si}$, (c) $\mathrm{Al}$, and (d) O from the region shown in (a). (e) Schematic of nucleation-site-dependent crystal orientation during inverted AIC.

based on $t_{\mathrm{Si}}$, whereas how crystal orientation depended on $T_{\mathrm{a}}$ was the same for all samples. Figure 3(d) shows the average grain size of the poly-Si layers as a function of the fraction of preferential orientation, showing that the higher fraction of the preferential orientation leads to a larger average grain size. This result shows that controlling the orientation is an effective way to increase the grain size in poly-Si layers formed by AIC.

The dominance of (100)- or (111)-oriented grains in the AIC-Si layers can be explained from the perspective of nucleation sites. Figures $4(\mathrm{a})-4$ (d) prove the stacked $\mathrm{Si} / \mathrm{Al} / \mathrm{SiO}_{2}$ structure of the inverted-AIC sample $\left(t_{\mathrm{Si}}: 50 \mathrm{~nm}, T_{\mathrm{a}}: 375^{\circ} \mathrm{C}\right)$. Figures 4(c) and 4(d) show the presence of a native $\mathrm{AlO}_{\mathrm{x}}$ layer on the $\mathrm{Si}$ surface, which was formed before layer exchange began. Figure 4(d) suggests that the $\mathrm{SiO}_{2}$ diffusion-limiting layer, purposely formed during sample preparation, remained between the $\mathrm{Si}$ and $\mathrm{Al}$ layers. The nuclei of group-IV semiconductors are preferentially oriented to (100) on $\mathrm{AlO}_{\mathrm{x}}$ and to (111) on $\mathrm{SiO}_{2}$, caused by minimization of interfacial energy. ${ }^{16,27,28}$ These orientations may explain why the AIC-Si layers consisted of only (100)- or (111)-oriented grains, as shown in Fig. 2. The dependence of crystal orientation on $t_{\mathrm{Si}}$ and $T_{\mathrm{a}}$ in the inverted-AIC-Si layer depends on the extent of supersaturation of $\mathrm{Si}$ in $\mathrm{Al}$, which is the driving force of the $\mathrm{Si}$ nucleation. In the AIC process, the supersaturation level of $\mathrm{Si}$ in $\mathrm{Al}$ increases for smaller volumes (i.e., thicknesses) of $\mathrm{Si} / \mathrm{Al}$ and lower annealing temperatures. ${ }^{16}$ At high levels of supersaturation, the Al layer likely splits the Si nuclei on a dense plane, i.e., the (111)-oriented Si nuclei, to reduce the $\mathrm{Si}$ concentration in Al. Because changing $t_{\mathrm{Si}}$ and $T_{\mathrm{a}}$ change the supersaturation level of $\mathrm{Si}$ in $\mathrm{Al}$, they also determine the orientation of the nucleating Si: (111) on $\mathrm{SiO}_{2}$ or (100) on $\mathrm{AlO}_{\mathrm{x}}$.

Based on this growth model, we can explain how controlling the orientation can change the grain size of the polySi layer grown by AIC, enabling larger grain sizes. Figure 4(e) shows a situation where $\mathrm{Si}$ can nucleate on both the $\mathrm{AlO}_{\mathrm{x}}$ and $\mathrm{SiO}_{2}$ layers. This situation leads to higher nucleation density as well as smaller grain size, because of competition between the (100)- and (111)-oriented nuclei. Thus, limiting the nucleation site, i.e., controlling the orientation to either (100) or (111), is essential for increasing the grain size of the AIC-Si layers.

Figure 5(a) shows a representative bright-field TEM image of the sample with $t_{\mathrm{Si}}=50 \mathrm{~nm}, T_{\mathrm{a}}=375^{\circ} \mathrm{C}$, which has the largest grain size $(\sim 40 \mu \mathrm{m})$ among the samples. Figures 5(b) and 5(c) show dark-field TEM images, using the $\mathrm{Si}$ $\{111\}$ plane reflection, taken to characterize defects in the poly-Si layer. In the Si layer processed for TEM $(\sim 7.3 \mu \mathrm{m}$ width), most regions contained no obvious defects [Fig. 5(b)], while a few regions contained some defects, including stacking faults [Fig. 5(c)]; note that TEM did not reveal disordered grain boundaries. Figures 5(d) and 5(e) show the selected-area electron-diffraction (SAED) patterns and the g-vector, respectively, taken from the region shown in Fig. 5(c). In both regions, the $\mathrm{Si}\langle 111\rangle$ direction was almost perpendicular to the substrate, demonstrating that the poly-Si layer consisted of large, (111)-oriented grains, a result which
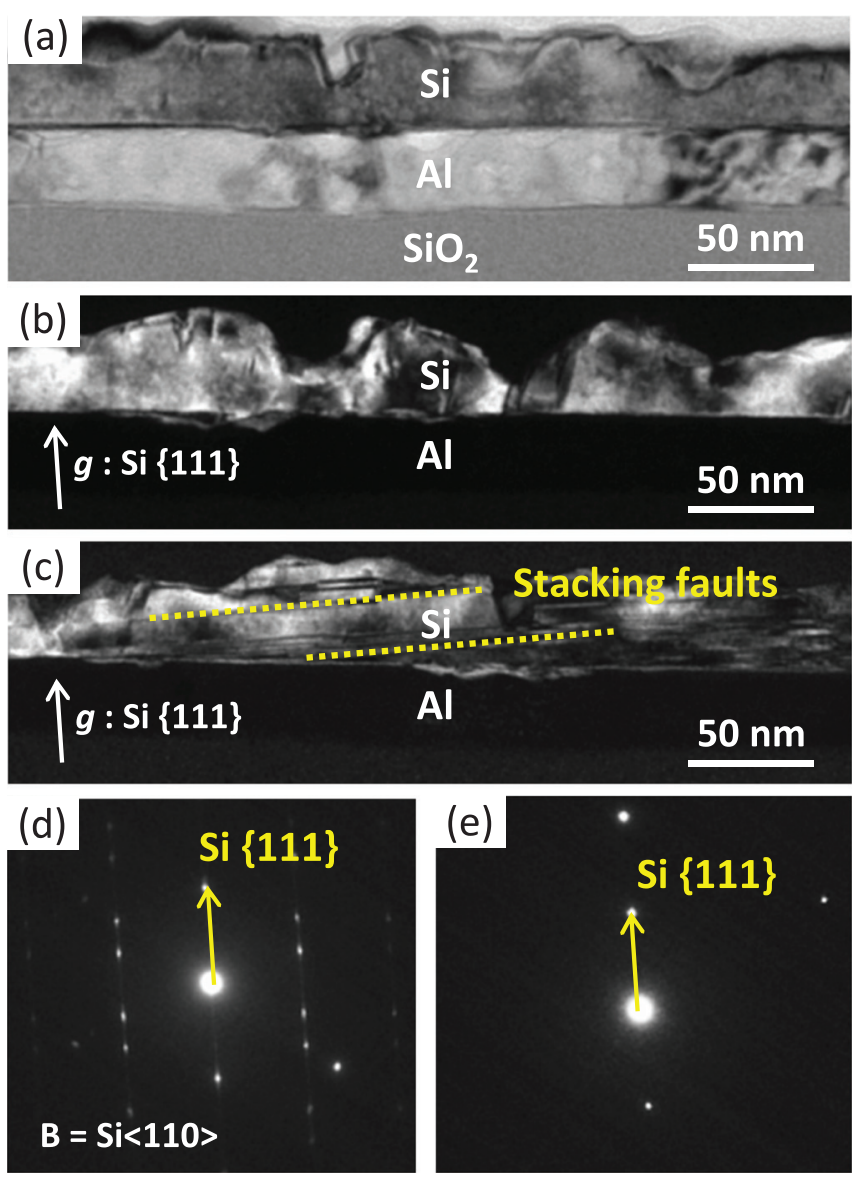

FIG. 5. Detailed TEM crystal structure of the sample with $t_{\mathrm{Si}}=50 \mathrm{~nm}$, $T_{\mathrm{a}}=375^{\circ} \mathrm{C}$. (a) Representative bright-field image. (b)-(c) Dark-field images using the $\mathrm{Si}\{111\}$ plane reflection showing single-crystal structures (b) without any defects and (c) with some defects, including a stacking fault. Typical stacking faults are indicated by yellow dotted lines. (d)-(e) SAED patterns showing the (d) $\mathrm{Si}\langle 110\rangle$ zone axis and the (e) g-vector, taken from the dark-field image shown in (c). 
agrees with the EBSD measurement. Figure 5(d) also shows a twinned Si structure and some streaking along the Si $\langle 111\rangle$ direction, caused by planar defects in the $\operatorname{Si}\{111\}$ planes. Because these defects were parallel to the substrate, no defects appeared on the Si surface. Thus, this Si layer is a promising epitaxial template for light-absorbing, low-defect Si layers and other advanced functional materials.

\section{CONCLUSION}

By using AIC, we selectively formed large-grained, (100)- and (111)-oriented $\mathrm{Si}$ on glass by controlling the annealing temperature and the Si thickness. We found that higher fractions of the preferential orientation led to a larger average grain size in the resulting poly-Si layer. Using this trend, we formed a $99 \%$ (111)-oriented Si layer with a large grain size $(\sim 40 \mu \mathrm{m})$ at a low temperature of $375^{\circ} \mathrm{C}$. These findings hold promise for developing high-efficiency thinfilm solar cells on inexpensive glass substrates.

\section{ACKNOWLEDGMENTS}

This work was partially supported by a Grant-in-Aid for Scientific Research from the Ministry of Education, Culture, Sport, Science, and Technology in Japan and the Yazaki Memorial Foundation for Science and Technology.

${ }^{1}$ M. A. Green, Sol. Energy 74, 181 (2003).

${ }^{2}$ W. Fuhs, S. Gall, B. Rau, M. Schmidt, and J. Schneider, Sol. Energy 77, 961 (2004).

${ }^{3}$ M. Imaizumi, T. Ito, M. Yamaguchi, and K. Kaneko, J. Appl. Phys. 81, 7635 (1997).

${ }^{4}$ P. Campbell, S. R. Wenham, and M. A. Green, Sol. Energy Mater. Sol. Cells 31, 133 (1993).

${ }^{5}$ Y. Cohin, O. Mauguin, L. Largeau, G. Patriarche, F. Glas, E. Søndergård, and J.-C. Harmand, Nano Lett. 13, 2743 (2013).
${ }^{6}$ D. Tsukada, Y. Matsumoto, R. Sasaki, M. Takeishi, T. Saito, N. Usami, and T. Suemasu, Appl. Phys. Express 2, 051601 (2009).

${ }^{7}$ O. Nast and A. J. Hartmann, J. Appl. Phys. 88, 716 (2000).

${ }^{8}$ Y. Sugimoto, N. Takata, T. Hirota, K. Ikeda, F. Yoshida, H. Nakashima, and H. Nakashima, Jpn. J. Appl. Phys., Part 1 44, 4770 (2005).

${ }^{9}$ J. Y. Wang, Z. M. Wang, and E. J. Mittemeijer, J. Appl. Phys. 102, 113523 (2007).

${ }^{10}$ B. I. Birajdar, T. Antesberger, B. Butz, M. Stutzmann, and E. Spiecker, Scr. Mater. 66, 550 (2012).

${ }^{11}$ O. Ebil, R. Aparicio, and R. Birkmire, Thin Solid Films 519, 178 (2010).

${ }^{12}$ C. C. Peng, C. K. Chung, and J. F. Lin, Acta Mater. 59, 6093 (2011).

${ }^{13}$ S. Y. Wei, S. M. Yu, L. C. Yu, W. C. Sun, C. K. Hsieh, T. S. Lin, C. H. Tsai, and F. R. Chen, Cryst. Eng. Commun. 14, 4967 (2012).

${ }^{14}$ M. Kurosawa, N. Kawabata, T. Sadoh, and M. Miyao, Appl. Phys. Lett. 95, 132103 (2009).

${ }^{15}$ M. Jung, A. Okada, T. Saito, T. Suemasu, and N. Usami, Appl. Phys. Express 3, 095803 (2010).

${ }^{16}$ A. Sarikov, J. Schneider, J. Berghold, M. Muske, I. Sieber, S. Gall, and W. Fuhs, J. Appl. Phys. 107, 114318 (2010).

${ }^{17}$ A. Okada, K. Toko, K. O. Hara, N. Usami, and T. Suemasu, J. Cryst. Growth 356, 65 (2012).

${ }^{18}$ P. I. Widenborg, A. Straub, and A. G. Aberle, J. Cryst. Growth 276, 19 (2005).

${ }^{19}$ I. Gordon, L. Carnel, D. Van Gestel, G. Beaucarne, and J. Poortmans, Thin Solid Films 516, 6984 (2008).

${ }^{20}$ B. R. Wu, S. Y. Lo, D. S. Wuu, S. L. Ou, H. Y. Mao, J. H. Wang, and R. H. Horng, Thin Solid Films 520, 5860 (2012).

${ }^{21}$ K. Y. Lee, C. Becker, M. Muske, F. Ruske, S. Gall, B. Rech, M. Berginski, and J. Huüpkes, Appl. Phys. Lett. 91, 241911 (2007).

${ }^{22}$ G. Ekanayake, T. Quinn, and H. S. Reehal, J. Cryst. Growth 293, 351 (2006).

${ }^{23}$ H. Kuraseko, N. Orita, H. Koaizawa, and M. Kondo, Appl. Phys. Express 2, 015501 (2009).

${ }^{24}$ C. Jaeger, M. Bator, S. Matich, and M. Stutzmann, J. Appl. Phys. 108, 113513 (2010).

${ }^{25}$ R. Numata, K. Toko, N. Saitoh, N. Yoshizawa, N. Usami, and T. Suemasu, Cryst. Growth Des. 13, 1767 (2013).

${ }^{26}$ K. Nakazawa, K. Toko, N. Usami, and T. Suemasu, ESC J. Solid State Sci. Technol. 2, Q195 (2013).

${ }^{27}$ J.-H. Park, T. Suzuki, M. Kurosawa, M. Miyao, and T. Sadoh, Appl. Phys. Lett. 103, 082102 (2013).

${ }^{28}$ A. A. Stekolnikov, J. Furthmüller, and F. Bechstedt, Phys. Rev. B 65, 115318 (2002) 